\title{
Electoral Management in Africa: A Facade or Reality-The Case of Election Dispute Resolution Mechanism
}

\author{
Joseph Kwaku Asamoah \\ Director of Training Centre at the Electoral Commission of Ghana, and a Facilitator at the Kofi Annan \\ Peacekeeping and Training Centre in Ghana. P O Box GP 19385, Accra. Ghana
}

\begin{abstract}
The restive citizens of most Africa countries continue to demand free and fair elections as the only democratic tool that equates the fundamental human rights. Even in some post conflict countries, the general public have adopted elections as a means of demanding accountability, good governance and independent and impartial election management bodies. Whereas elections have become commonplace in Africa over the past decades, some recent elections have failed to legitimise power by creating tension and causing violence. Understanding the dynamics around electoral violence has become fundamental to limiting the risk of electoral violence to improve the quality of democracy in Africa. The purpose of this article, therefore, is to examine how EMBs and the judicial system can prevent electoral violence, followed by an assessment of the role stakeholders and effective electoral cycle management play in preventing election related disputes. The study uses uses the politico-legal debates to support the argument of causes of electoral violence on the African continent and ways to prevent them. The study suggests that an independent and impartial EMBs and judiciary are prerequisites for effective election dispute resolution mechanisms. The again concludes that the multi-stakeholder conflict management, which brings together various types of actors and supports social diversity, is fundamental to promoting peaceful electoral processes in Africa.
\end{abstract}

Keywords: electoral violence, election management bodies, stakeholder management, election dispute resolution

DOI: $10.7176 /$ PPAR/9-7-01

Publication date:July $31^{\text {st }} 2019$

\section{Introduction}

Since the early 1990s, elections have become an important democratic imperative in almost all African states and are now a mandatory tool for accessing or retaining a political power. Recent global democratic trend reflects the view that, in Africa and beyond, citizens value elections. Elections have contributed to the emergence of democratic governments in Ghana, Benin, Cape Verde, Senegal, and South Africa. Some Africa countries like Liberia and Sierra Leone that were engaged in civil war and protracted conflict have even come out to hold credible elections. There has been legitimate power alternation between incumbent governments and opposition parties in some African countries since the adoption of multi-party democracy. For example, Ghana's 2016 and the Liberian 2018 presidential elections which were notably competitive, the ruling parties handed power over to the opposition parties, reaffirming the entrenchment of democracy in Africa. The universal acceptance of elections in Africa is as a result of the growing expectations of citizens to demand accountable governance.

Indeed, democracy has seen growth in many African societies. According International Foundation for Electoral Systems (2014), 29 out of the 54 countries on the Africa continent held elections in 2015. However, the fact that electoral processes have now become commonplace does not imply political stability in Africa, particularly in countries that lack the necessary political and technical infrastructure to deal or prevent electionrelated violence. In some cases, elections have been manipulated to legitimate autocratic regimes or to ensure dynastic successions on the continent (International Peace Institute, 2011). A study by Bekoe (2010) indicates that violence affects about 20 to 25 percent of elections in Africa. Elections in Africa have become periods of despair and anxiety for contesting candidates as well as the general citizenry whose efforts to seek new leadership for their respective countries often prove abortive (Vorobyev, 2010). Authoritarian regimes like Egypt, Togo, Zimbabwe and recently in Benin have been able to exploit the symbol of elections by abusing them through fraud and skewed procedures. Over the past decade, electoral processes have become triggers of violence in several African countries: The Democratic Republic of Congo (2006 and 2018), Togo (2005), Nigeria (2007), Lesotho (2007), Guinea-Bissau (2008), and Senegal (2012). In Kenya, flawed elections conducted in 2007 left a trail of disaster which manifested itself through ethnic clashes, leading to the death of over 1000 people. Likewise, the 2008 elections in Zimbabwe took violent dimension when political leaders anticipated defeat (Masunungure, 2009). Electoral violence that characterised these elections led to loss of many lives and human displacement. In each of these cases, election lost its democratic value and failed to confer legitimacy on the political authority.

Tensions over land rights, employment and ethnic marginalization, religion and access to national resources and wealth are the dominant characteristics of recurring electoral violence (Bekoe, 2010). Such is the case in 
Africa, where loss of electoral contest leads to the exclusion of the losers and their followers from accessing public resources. According to Masunnungure (2009), elections are periods where the political incumbent takes stock of achievement to assess whether they will survive the electoral contest through abuse of state resources. For the opposition, elections are period to prove during campaign that they have better proposals of solving the plight of the citizenry than the incumbent party. This is also the period for the opposition to endure political harassment, intimidation and exclusion from the use of state facility (Melber, 2002). Hammar (2008) posits that elections in Africa also presents opportunity for contesting candidates to feed the electorate with menu of lies, falsehood, confusion and misconceptions. During this time, the risk of instability is particularly high in fragile political regimes. Although elections tend to heighten tensions and engender violence, the intention is not to question their democratic value for citizens to select their political leaders.

The question therefore is whether elections in Africa do not meet the standards and guiding principles of transparency, fairness and freeness in order to guarantee their acceptability from all stakeholder in order to promote peace. According to Calingaert (2006), the entire electoral process in many countries is susceptible to fraud. This means that if African leaders mean well to embrace electoral democracy, they must fight against practices that undermine democratic elections. Many areas of election administration in Africa require legal and administrative reforms to enable Africa benefit from electoral dividends. This article focuses on assessing the failings and strengths of electoral management bodies and election dispute resolution mechanism that contributes or militates against electoral governance in Africa. These issues are at the core of securing transparent, free and fair election. They are also essential ingredients to African countries that are committed to respecting, promoting, and protecting the fundamental right to vote. Given the experience of electoral crises in some African countries like Gabon, Kenya, Nigeria, and Zimbabwe, and the threats they pose to democratic ambitions, it is important to explore available options for strengthening election institutions and mechanism for managing election related violence and the impact of such options and their prospects for future elections. It is the view of this article that electoral reforms in these areas could enable African states strike a successful balance between democratic participation and governance.

\section{Electoral Management}

Elections and their administration remain the most complicated, time-bound and action-packed activities undertaken by electoral institutions. At every stage of the electoral cycle, election management bodies (EMBs) should discharge their duties in a professional manner to allow citizens the opportunity to participate and make informed decisions about the leaders who will govern them. The quality and credibility of elections depend on the establishment of an effective, stable and legitimate administrative system. According to Duodu (2010), for a country to organize credible, free and fair elections, certain institutional framework should be put in place. This institutional structure provides fair avenue for citizens to freely to elect and be elected under rules and regulations that are clear to all contesting parties (Hammer, 2009). Some of the institutional and political architecture involve the establishment of independent electoral management bodies (EMBs) that seek to preside over free and fair electoral processes. Election management bodies are public institutions that play an important role in securing, protecting, and promoting democracy in any state. These bodies have become the cornerstones of the electoral process (OSIWA, 2011). The core activities of EMBs are (1) determining who is eligible to vote, (2) receiving and validating the nominations of the participating parties and candidates, (3) conducting the polling, (4) counting the votes, and (5) disseminating the results (Wall et al., 2006). By performing these activities, the EMB has to ensure that the elections are conducted and managed in a way that is efficient, transparent and fair. Failure to do so can trigger electoral violence as was the case in 2007 elections (Jacobs 2011).

Given the control that election management bodies have over the electoral process, they need to be independent and impartial to enhance citizen confidence in the electoral process. Election Management Bodies that are not widely viewed as impartial can fatally damage the credibility of the election. The quality and performance of election administrators have a strong impact on whether or not electoral violence occurs (UNDP, 2009). Positive attributes such as inclusive membership structure, political balance and professionalism to these bodies, could contribute to the legitimacy of the election and, if absent, can trigger election-related violence (Sisk, 2008). There are different types of electoral management bodies and administration models in Africa. According to Lopez-Pintor (2000), elections can be administered by the government; by the government but under supervision of an independent authority; or by an independent commission.

While administration of election may be fairly done by the government-based in advanced democracies, in a fragile economies and conflict prone divided countries with ethnic cleavages, government-based electoral administrations face legitimacy issues and accusations of manipulation by the incumbent (Pastor, 1999; LopezPintor 2000). The credibility of these EMBs therefore rests on their independence, representativeness and sustainability of the body, and professionalism and credibility of the members of the election body. These were the appeasing factors taken into consideration in composing the Tunisia Independent High Authority for 
Elections to manage the 2011 electoral process following the political turmoil. Preponderance of evidence in some African countries point to the fact that elections run by independent election management bodies are more successful with the outcome of the elections fully respected and uncontroverted. It is for this reason that LopezPintor (2000) points out that historical evidence as well as recent conclusions by observers, analysts and practitioners, almost unanimously indicates that elections run by independent electoral bodies are preferable to those run by executives.

However, just like the electoral system, the electoral administration model is often not deliberately chosen but a product of the colonial inheritance (Jinadu, 1997; Wall et al., 2006). The role of Independent Electoral Management Bodies (EMBs) is very critical to the outcome of an election as these electoral bodies derive their powers and mandate from the national constitutions and laws of the various state (Makumbe, 2009). However, in conflict prone and volatile societies, the decision of the election management body regarding the eligibility criteria for contesting candidates and voter registration is often characterized with mistrust and seen as partial to rival groups which has the tendency of endangering the entire electoral process. Studies have pointed to weak institutions and institutional rules governing the election process as one of the main contributing factors to postelection violence (Khadiagala, 2009; Baregu 2009). Zeev and Russett (1993) posit that the frequency of political and electoral violence is closely related to the degree of performance by electoral institutions. This supports the assertation by Eklit and Reynold (2002) that, acceptability of election results is dependent of whether a particular state has created an autonomous and independent election management bodies with the responsibility of conducting elections professionally and impartially. Example of such election management bodies is the Electoral Commission of Ghana and Independent Electoral Commission of South Africa.

The nature, intensity and consequent outcomes of electoral violence in African countries have taken different dimensions and forms. According to Sisk (2008), the risks associated with organizing elections becomes high, if the electoral process is not managed professionally and impartially by a trusted institution. The recent clashes in Mali, Togo, Democratic republic of Congo and Sudan are all reflective of the view that, the will of the people are not considered be the sacred outcome of political contest. It is worthy to posit that not only can the EMB create electoral tension by the way it organises the election, its own composition, and related behaviour of its members, can also become a focal source of electoral conflict. This means that electoral violence may emanate from deficiencies in the electoral process itself as much as it may be stimulated by underlying social, political and economic cleavages or tensions.

In many African countries, the whole concept of election administration by these election management bodies is failing, from the primary activity of voters' registration and conduct of credible elections to the judicial bodies in charge of electoral disputes. For elections to be successful, it is essential that the EMB ensures the integrity of the elections. This can significantly reduce the likelihood of election-related violence. Electoral malpractice undermines public confidence in the credibility of the elections and increases the risk of protests (Norris, 2012). Past experience has revealed that discredited election management bodies are incapable of managing a competitive electoral contest and often find themselves at the core of controversy (Kriger, 2011).

In most countries, the election management body is a permanent, specialized agency. The EMB should take decisions independently, without being subjected to partisan influences. In most Africa countries like Ghana, South Africa and Nigeria, the electoral body has exclusive legal mandate to handle all aspect of the electoral process. For example, in Ghana, Article 45 of the 1992 Constitution create the Electoral Commission as the only single body mandated to manage every aspect of the electoral process. The fact that these election management bodies manage critical activities such as the right to vote which are of high interest to contesting candidates and parties, make it vulnerable to political interference. An electoral commission that is structurally independent from government and consists of neutral experts will generally be perceived as impartial because it has no political affiliation. Government-based models, especially in post-conflict states, may be suspected of working to the advantage of the incumbent (Wall et al. 2006). The authority and competence of the EMB are dependent on the technical ability of its members (Elklit and Reynolds 2002).

To achieve institutional strength and autonomy to insulate the EMBs from control and direction by any external organs of the state, the constitution of various African countries such Kenya (Article 41 of the 2008 Constitution), Ghana (Article 46 of the 1992 Constitution), Zimbabwe (Article 61 of the 1979 Constitution) has placed considerable emphasis on the independence of the Election Management Bodies. For example, in South Sudan, to qualify as a member of the National Elections Commission (NEC), which is responsible for the organization and management of the elections, a person should be of proven integrity, independent, competent, non-partisan and impartial (National Elections Act, 2012). One would expect that based on these constitutional guarantees, these electoral bodies and the individual commissioners would to be guided exclusively by the law in the discharge of their mandate.

However, despite these constitutional protections, election bodies in some African countries are vulnerable to conduct credible elections due to the mode of appointment of the members of these Commissions. According to Lindberg (2008), the process of appointing members of the EMB goes to the heart of guaranteeing a free and 
fair elections. Several works on democracy in Africa and elsewhere have also underscored the importance of having a broad-based, as opposed to unilateral, appointing authority (Harris, 1999; Pottie, 2001; Gyima-Boadu, 1998; Hasen, 2005; Emert et al, 2007). Freeman (2006), reveals that the process of appointment of the members of election management bodies should inspire confidence in the public that the members will perform and discharge their mandate in accordance with the law. This means that the principle of unilateral appointment process by the government of the day has the proclivity of reducing the appearance of independence of the electoral body. Elkit, Jorgen and Reynolds (2002) affirms that staff recruitment has a significant impact on the quality of an election and credibility of the election management body. Accordingly, the possibility of partiality on the part of the election management body or an individual official of the body is likely to cast doubt on the entire electoral process.

Abuya (2009) established the extent of severity and consequences of a flawed presidential election. Thompson and Kuntz (2005) posit that stolen presidential elections often trigger widespread outrage. It is therefore averred that the perceived fairness of an elections is based not only on how the election management body as an institution is perceived, but also on the extent to which individual commissioners are seen to be neutral (Southall and Fox, 1999). It is on this reason that the Commonwealth Expert Team in the Sri Lankan 2005 Presidential Election, expressed concern about sitting presidents appointing members of the election management bodies especially if the president is also a candidate in the electoral contest. This was the case that resulted to chaos and electoral violence in both the 2007 election in Kenya and the 2008 election in Zimbabwe. A case in point is Uganda where prior to the 2011 general election, the president who was also the presidential candidate of the ruling National Resistance Movement (NRM) appointed the members of the Electoral Commission of Uganda. The opposition became very critical and suspicious of all actions taken by the electoral commission, even the ones that could have led to reforming the electoral process in Uganda. This mistrust fueled political tension leading up to the 2011 election (EU Election Observation Mission Report, 2011).

Experience show that the appointment of members of the election bodies by the president of a country is not in itself an unsurmountable problem. For example, in countries like the United Kingdom and Australia, members of the Electoral Commission are appointed by the Queen and Governor-General, respectively. The challenge of this mode of appointment in Africa, however, lies in whether these appointed members would be neutral to delivers elections in line with internationally acceptable standards and are in compliance with the legal and regulatory framework governing the elections. Studies in Botswana (Sebudubudu and Osei-Hwedie, 2005) and Lesotho (Tsikoane, 2007) suggests that an all-inclusive appointment process could minimize doubts over the impartiality of the election management body as well as contribute to the success and credibility of elections. Sofie and Wagner (2013) also suggest that the principles of descriptive representation can be adopted for the composition of election management bodies in conflict prone societies to enable the EMB prevent allegations of perceived partiality. Descriptive representation is where a member of an ethnic or minority group represent them in the EMB to build trust among people that the EMB will handle its politically sensitive mandate in an objective manner.

Again, security of tenure of the members of election management bodies could impact of the professional performance of such institutions. Commission members must have the mandate to make independent decisions, and must have the space and means to do their work. In Kenya and Zimbabwe, the independence Commission was strengthened by the fact that its commissioners were given a constitutional tenure of five-years once appointed. However, in Ghana, the members of the Commission have life time security of tenure until they are retired from public service. The Chairman of the Commission retires at the age of seventy (70) years, the two Deputy Chairmen retires at the age of sixty-five (65) years and the four other members of the Commission also retire at the age of sixty (60) years. The long-term security of tenure may guarantee the independence of the EMBs. Frequent state intervention, influence and rotation of member of these Commission prevents election bodies from executing their function in the interest of the public. In this way, the absence of functional and administrative independence on the part of the Electoral Commission (EC) to enforce rules and decision, can always lead to suspicion and non-acceptability of election results by opposition parties and the general public. In this circumstance, parties and groups who feel defrauded by the electoral process will resort to non-democratic forms of protests, riot and violence.

The nexus between electoral fraud and violence can present a situation where voter confidence in the electoral process is eroded which can trigger violence after the declaration of the election results. Fraud-induced violence can occur at every phase of the electoral cycle. Crucial to the concept of electoral violence is the avoidable electoral administrative errors committed by unprofessional electoral bodies. Electoral violence takes place in a context of uncertainty, fear and mistrust. In such an environment administrative errors are likely to trigger violence if a contesting party perceives that the electoral body is skewing the electoral process to favour a rival candidate. Pastor (1999: 1) succinctly state that "many elections fail because one party interprets a 'technical irregularity' as politically-inspired by its opponents, whereas it might be due to administrative failures". For example, the results of the 2012 elections Ghana were challenged by the New Patriotic Party 
(NPP), the then opposition party on grounds of voting fraud and administrative errors on the part of the Electoral Commission of Ghana. It is thus of vital importance that the EMB can reassure the population in general and the contesting parties that an administrative error on the part of the electoral body was unintended and an exception, rather than the rule. There are a number of guiding principles for EMBs to gain this public confidence. According Pastor (1999) an EMB that is independent, impartial, authoritative, and competent, and perceived as such, with adequate resources and capacity, has a far greater likelihood of conducting an election that is judged fair and free by all parties in a country and by the international community than one that does not have these attributes.

According to (IFES, 2014), newly established electoral bodies may suffer from lack of knowledge and experience, which may be confused with corruption or malpractice. These EMBs require enough time for effective election management to prevent fraud at every stage of the electoral process. It is established that, in post-conflict elections, the influence of electoral institutions and the design of the electoral system play an important role in encouraging peace building and reducing the chances of electoral violence (Sisk, 2008). This calls on professional electoral body to put a framework in place to mitigate emerging and potential electoral threats that could degenerate into electoral violence. Table 1 shows electoral threats at the various phases of the electoral process:

Table 1. Phases of Electoral Threat

\begin{tabular}{|c|c|}
\hline Election Phase & Threats and Tactics \\
\hline $\begin{array}{l}\text { Phase I: The Long } \\
\text { Run- Up to } \\
\text { Electoral Events: } 18 \text { months to } \\
\text { months before Election Day }\end{array}$ & $\begin{array}{l}\text { Intimidation or removal of independent judges Intimidation or targeting of } \\
\text { election officials } \\
\text { Intimidation or harassment of journalists } \\
\text { Incitement to violence in the media or public venue } \\
\text { Police or internal intelligence ser vices targeting of meetings of opposition } \\
\text { figures } \\
\text { Protecting, expanding, or delineating turf or 'no-go zones' Increased rates of } \\
\text { hostage-taking, kidnapping, and extortion }\end{array}$ \\
\hline $\begin{array}{l}\text { Phase II: The } \\
\text { Campaign's Final Lap }\end{array}$ & $\begin{array}{l}\text { Clashes between rival groups of supporters Attacks on election rallies or } \\
\text { candidates Bomb scares } \\
\text { Attacks or intimidation of election officials } \\
\text { Attacks on observers, domestic and international }\end{array}$ \\
\hline Phase III: Polling Day & $\begin{array}{l}\text { Attacks by armed rebel groups to disrupt the polling, to limit turnout, or to } \\
\text { attack security forces on police stations } \\
\text { Intimidation of voters to compel them to vote or stay away } \\
\text { Attacks on election administrators or observers } \\
\text { Physical attacks on election materials such as destruction of ballot boxes }\end{array}$ \\
\hline $\begin{array}{l}\text { Phase IV: Between } \\
\text { Voting and Proclamation }\end{array}$ & $\begin{array}{l}\text { Armed clashes among political par ties } \\
\text { Violent clashes among groups of rival supporters Vandalism and physical } \\
\text { attacks on proper ty of opponents targeted attacks against specific candidates } \\
\text { or political par ties }\end{array}$ \\
\hline $\begin{array}{l}\text { Phase V: Post-Election } \\
\text { Outcomes and } \\
\text { Their Aftermath }\end{array}$ & $\begin{array}{l}\text { Attacks on rivals who have either won in elections, or were defeated } \\
\text { Violent street protests and efforts by armed riot police to maintain or restore } \\
\text { order, tear gas, firing on protestors, attacks by protestors on proper ty or the } \\
\text { police } \\
\text { Emergence of armed resistance groups against an elected government } \\
\text { Escalation and perpetuation of ethnic or sectarian violence. }\end{array}$ \\
\hline
\end{tabular}
Source: United States Agency for International Development (2010)

Some African states demanded an impartial body to run elections at the time of adopting their national constitutions. Various legal jurisprudence has also demanded impartiality from election management bodies. For instance, in the case of the Republican Party v. Malawi Electoral Commission and Others (Constitutional Case No. 5, 2004), the Malawian Constitutional Court argued that an election management body must be in fact proactive and independent in the discharge of its functions and that any traits short of this would present difficulty in the acceptability of election results. To this end, attempts have been made by some African countries to restore confidence in the composition of the membership of their election management bodies. For example, in Zimbabwe, to miminise the president's influence over the appointment of the Chairperson of the Electoral Commission, the laws now require the president to do so in consultation with the Judicial Service Commission. In 2008, the Constitution of Kenya was also amended to pave way for the members of Independent Electoral and Boundary Commission (IEBC) to be appointed jointly by the president and the official leader of Opposition 
(Constitution of Kenya Review Act, 2008). The independence of the EMB is measured not only in terms of the appointment of its members, but also according to each member's credibility and past record (Aaken, 2007). The individual member of the election bodies must not only be neutral, but also be seen to be impartial in the discharge of their duties. Prior to the 2008 Zimbabwe election, various stakeholders and opposition parties expressed doubts as to the ability of the Electoral Commission of Zimbabwe to be impartial, due to the close association between its members and president Robert Mugabi. Similar doubts were expressed prior to 2007 Kenya election, where the vice-chairperson of the Independent Electoral and Boundary Commission, Kihara Muttu, had previously acted as the personal Lawyer for the then incumbent President, Moi Kibaki.

To prevent electoral violence in Africa, the core assignment of the election management bodies is to conduct elections with integrity, credibility and free and fair in order to guarantee the acceptability of the election results to prevent the electoral body from accusation of fraud. When designing the criteria for membership of the electoral bodies, it is recommended to adopt independent model to avoid mistrust and suspicions from contesting parties that can degenerate into electoral violence. Election management bodies must commit to the principles of independence and impartiality in order to achieve the buy-in by candidates and the general public. This would enable these EMBs to conduct elections that comply with laws to avoid interference of state actor in the discharge of their functions. In order to professionalise itself, the commission should undertake intensive capacity building trainings to minimise the number of disputes that would arise as a result of the electoral administration.

\section{Electoral Dispute Resolution}

The Universal Declaration of Human Rights (1948) as well as the International Covenant on Civil and Political Rights adopted in (1966) both recognise that the legitimacy and the basis of authority of government must be expressed by the will of the people through free and fair elections. The African Charter on Human and Peoples' Rights (1981) affirms these Treaties by stating that every citizen has the right to participate freely in the government of his or her country whether directly or through democratically elected representatives. This makes elections an essential component to institutionalise legitimate power. However, the management and organization of elections in some African countries that should respect universal suffrage as a basic human right have often degenerated into a full-blown conflict. Election-related conflict is one of the major threats to democracy and political stability in Africa. The credibility of elections and stability of the election environment hinge on the capacity of the State to effectively resolve these disputes throughout the electoral cycle.

Whiles most international and domestic standards for assessing credibility of election have focused on the electoral process, not much attention has been given to electoral dispute resolution as a mechanism for reducing conflict in Africa. The stability of electoral processes largely depends on the way in which electoral tensions are managed. Crouzel (2014) posits that responses towards the management of electoral dispute in Africa have generally been of a reactive nature, responding to the crisis rather than prioritising the prevention of the violence. According to Sweeney (2016), mechanisms for election dispute resolution (EDR) must withstand the test of political manipulation or attempts by autocratic leaders in Africa to use the judicial system to legitimize staying in power. The EDR mechanism should therefore serve as an effective remedy to address electoral manipulation, impunity for violence, intimidation and harassment associated with electoral contest. A refusal by opposition parties or losing candidates to accept electoral outcomes can undermine the authority of the government, weaken trust in democracy and democratic institutions, and in extreme cases trigger violence. Electoral losers play a crucial role in the functioning and development of democratic political institutions and that their perceptions of the system's legitimacy have potentially critical effects on that system's proper functioning and maintenance (Mendes et al., 2009).

Election disputes are inherent to elections. Therefore, challenging the conduct of an election or its results, should however not be perceived as a reflection of weakness in the electoral system, but as proof of the strength, vitality, and openness of the political system. This underscores the capacity of the state to deal with electoral conflict. Studies into the acceptance of election results suggests that both the rules governing an electoral process (Przeworski, 1991) and the experience of the institutions and individuals administering those rules (Atkeson and Saunders, 2003) are important to public perceptions of an electoral process and outcome. Przeworski contends that democracy is a system of ruled "organized uncertainty" whereby electoral outcomes must be uncertain to ensure participation in competition, but the system or process for political competition must be governed by rules. In recent years, randomised control trials have been used to test the link between procedural justice, public perceptions, and public behavior. In summarizing the results of these trials, academic Kristina Murphy observed: "researchers have typically found that members of the public who have interactions with procedurally just authorities are significantly more likely to evaluate those authorities positively and are more willing to display cooperative and compliant behaviours." (Kristina, 2017, pp.43). In electoral practice, a complaint or petition, generally, may refer to the original submission of an application for relief from a violation of electoral law, regulations or procedures. These complaints may be filed at any level of electoral cycle to the body directly 
responsible for taking a required action.

Electoral dispute resolution mechanisms vary greatly country-by-country, based largely on historical and political context. Identifying obligations for EDR, based on public international law has proven difficult because international obligations related to dispute resolution have not necessarily been tied explicitly to the electoral process. Public international law appears only to provide the highest-level guidance regarding the resolution of disputes. The International Covenant on Civil and Political Rights (ICCPR) (1966) and regional treaties such as African Union Declaration on the Principles Governing Democratic Elections in Africa stipulate a number of obligations upon States Parties which provide a broad framework for the resolution of disputes. These international treaties on democracy require that persons whose civil or political rights have been violated are entitled effective remedy. In its General Comment No. 31, the UNHRC interpreted this article to require states to make available judicial and administrative and other means to remedy violations. According to the UNHRC, states must respond to violations even if they are committed by other branches or levels of government, or by third parties. According to United States Agency for International Development (USAID) Report on Electoral Security Framework (2010), institutions charged with the responsibility of resolving electoral disputes must be impartial and equipped to fairly and transparently adjudicate disputes so that the grievances do not turn violent. The ACE Electoral Knowledge Network classifies election dispute systems as conducted by the judiciary, EMBs, or specially appointed election tribunals, among other bodies. Table 2 shows a global survey of such models.

Table 2. Electoral Dispute Resolution Mechanisms

\begin{tabular}{|c|c|c|}
\hline Institution & Number of Countries & $\%$ of Countries \\
\hline \multirow{6}{*}{$\begin{array}{l}\text { Judiciary } \\
\text { EMB } \\
\text { Specially Electoral Tribunal } \\
\text { Other } \\
\text { No Information available } \\
\text { Not Applicable } \\
\end{array}$} & \begin{tabular}{r|r}
103 \\
\cline { 2 - 2 }
\end{tabular} & $51.7 \%$ \\
\hline & 89 & $44.7 \%$ \\
\hline & 30 & $15.0 \%$ \\
\hline & 24 & $12.0 \%$ \\
\hline & 5 & $2.5 \%$ \\
\hline & 1 & $0.5 \%$ \\
\hline
\end{tabular}

Source: ACE Electoral Knowledge Network

In some post-conflict countries, the international community has established an adhoc election dispute resolution mechanisms to oversee and adjudicate on electoral complaints. Examples include Bosnia and Herzegovina (1996), the Electoral Appeals Sub-Commission (EASC) in Kosovo (2000) and the Electoral Complaints Commission (ECC) in Afghanistan (2005- 2009). The setup of these conflict resolution bodies managed to reduce tension and acrimony that greeted elections in those countries (IFES, 2010). For the first time in the history of Afghanistan, the Electoral Complaints Commission played a pivotal role in investigating and adjudicating fraud, sending the 2019 election to second round. Despite these gains in other environment, in Africa, the compliance level to international standards and treaties governing democratic elections have not been encouraging. Electoral Dispute Resolution mechanisms have not received the same amount of analysis and attention that other aspects of the electoral process, such as voter registration, have.

While some scholars and practitioners have focused on a broad array of issues related to election disputes, this study focuses on a narrower set of issues related to the interaction between the electoral process and judicial system mediated principally by the right to a fair and impartial hearing and those that are related to the provision of an effective remedy to prevent violence. In the context of the electoral process, EDR involves the system of judicial or quasi-judicial mechanisms through which electoral actions can be legally challenged and electoral rights protected. In the context of the judicial system, EDR is defined as any form of remedial actions through which the State provides redress for violations of Covenant rights. This article seeks to explore the model and structure of electoral dispute resolution in Africa from the regulatory framework and electoral governance institution approach. Whiles the legislative and regulatory approach adopts adjudicatory model for election dispute resolution, the electoral governance approach adopts a preventive model using matrix of inclusion.

\subsection{Legislative and Regulatory Approach}

This is where the necessary constitutional, legislative and regulatory framework have been put in place by a country to deal with the management of election related conflicts. This include the establishment of election tribunals or electoral courts for resolving election disputes in Africa. Article 14 of the International Covenant on Civil and Political Rights (ICCPR) and Article 10 of the Universal Declaration of Human Rights (UDHR) guarantee the right to due process. That is, all people are equally entitled to a fair and public hearing by a competent, independent and impartial tribunal established by law. This right to due process is well recognized in traditional court systems, but is an equally essential right in the adjudication of electoral disputes. According to the International Center for Transitional Justice, widespread violations of human rights call for transitional justice responses. All States must take necessary steps to ensure the realisation of human rights (ICCPR, 1966). This obligation requires states to take legislative and other measures to ensure that human rights are fulfilled and 
protected. Effective EDR mechanisms, through which fundamental rights and freedoms are protected, are essential components to determining whether the election can truly be considered genuine and a reflection of the will of the people (AU Declaration on the Principles Governing Democratic Elections in Africa, 2002).

Studies of the 2000 U.S. Supreme Court decision in Bush v. Gore suggest that in gaining acceptance of a controversial decision, the Court benefitted from the widespread view of the Court as a legitimate institution (Gibson et al., 2003). In contrast, Carter Center observers report on the 2011 presidential elections in the Democratic Republic of the Congo (DRC) suggested that citizens' belief in the inadequacy of the DRC's dispute resolution mechanism may have contributed to widespread protest and violence during the electoral cycle as citizens resorted to protest, frustrated that there were no other avenues to express their grievances (Carter Center Final Report, 2011). This points to the fact that the underdeveloped system in some political environment do not sufficiently protect citizens' fundamental right to adjudicative remedy for alleged violations of their rights. To this end, strengthening EDR processes in ways that are visible to the public prior to an election can be essential to public confidence.

Elections in Africa are always fiercely contested. As a result, most African countries anticipated the possibility of electoral dispute among stakeholders and have instituted constitutional and statutory framework to handle such disputes. Section 285(1-3) of The Nigerian Constitution of 1999, for example, provides for election tribunals to handle post-elections petitions. Section 285 (1) states that: 'There shall be established for the federation one or more election tribunals to be known as the National Assembly Election Tribunals which shall, to the exclusion of any court or tribunal, have original jurisdiction to hear and determine petitions". Similar provisions are contained in the constitutions of most African countries under the new era of electoral democracy.

In respect of Complaint Procedures and Judicial Review in Post conflict Liberia, the Liberian Constitution, Article 83 (c) reads that "Any party or candidate who complains about the manner in which the elections were conducted or who challenges the results thereof shall have the right to file a complaint with the Elections Commission. Such complaint must be filed not later than seven days after the announcement of the results of the elections." In the Southern African region (SADC), courts are legally empowered to mediate in pre-election, election and post-election disputes. In Botswana, for example, section 132 of the Electoral Act provide that election petitions be heard by the High Court, in which case petitions must be submitted within 30 days of the announcement of the result that is disputed. In Angola, complaints during registration of voters can be presented to the provincial courts. During the voting process and in the post-electoral phase, complaints are filed with the Supreme Court. Candidates and their mandatories are in a position to filed such complaints (Fandrych, 2003).

However, in some jurisdictions, the consideration given EDR is shared by different state institutions. For example, in Kenya, jurisdiction over various types of electoral disputes and violations resides with both the Independent Electoral and Boundaries Commission (IEBC) and Political Parties Disputes Tribunal (PPDT), while jurisdiction for electoral offenses is with the Office of the Director of Public Prosecutions (ODPP), and jurisdiction for post-election petitions the judiciary (High Courts, Court of Appeal, and Supreme Court). Despite this shared jurisdiction, each body has responsibility to provide due process protections when resolving complaints and disputes of all types. According Icelandic Human Rights Centre (2017), procedural justice encapsulates the right to be treated fairly, and to receive an effective remedy, through an efficient and transparent administration of justice. This involves both the protection of due process and the advancement of open justice. If the courts are legitimate venues for justice, then judicial remedies can be employed to rectify the impact of violence on an election. The question is whether the judicial system in most African states are independent to administer justice in the midst of heated electoral contest where the stakes are high. Whiles the judicial system in some African countries demonstrated the willingness to apply the law with fear or favour, others have failed to deliver electoral justice. Countries like Ghana and South Africa are prominent examples judicial assertiveness and independence.

On the contrary, the constitutional court of Cote D'Ivoire failed to administer after 2007 elections by invalidating the election results declared by the Electoral Commission in favour of the then incumbent president, Laurent Gbagbo. This decision of the court resulted to post electoral civil unrest. In recent times, however, the judicial system in some electorally conflict prone countries on the African continent have also demonstrated readiness to exact justice on election related disputes. For example, in Nigeria, the ordinary courts over turned an election that was deemed to be too violent and fraudulent. The Court of Appeals in Ibadan, Nigeria, nullified the results of a senatorial election because it was marred by violence, thuggery, and intimidation (Ajayi, 2009). Domestic courts also play a role in redressing the grievances of the victims of electoral violence. This redress does not only include the prosecution of the perpetrators, but also the consideration of reparations for untimely death, disabling injury or property destruction (Hansen, 2009).

The jurisprudence that emphasizes the importance of courts and tribunals to conduct their public duty to safeguard against judicial bias, unfairness and incompetence, is articulated in Article 14(1) of the ICCPR (1966) and the UNHRC General Comment 32 (2000). This principle of justice is encapsulated in the quote of Lord Hewart of the United Kingdom House of Lords, now the Supreme Court of United Kingdom that "justice should 
not only be done, but should manifestly and undoubtedly be seen to be done." (Spigelman, 2000). According to this principle, any institution dealing with the adjudication and resolution of election disputes must operate with a high degree of transparency, independence and accountability. This means that for the adjudicatory approach to election dispute resolution to realise its potential of dealing with electon dispute and conflict, it must involve procedural justice, due process and open justice. Figure 1 shows the study's model of election dispute resolution mechanism using the adjudicatory approach.

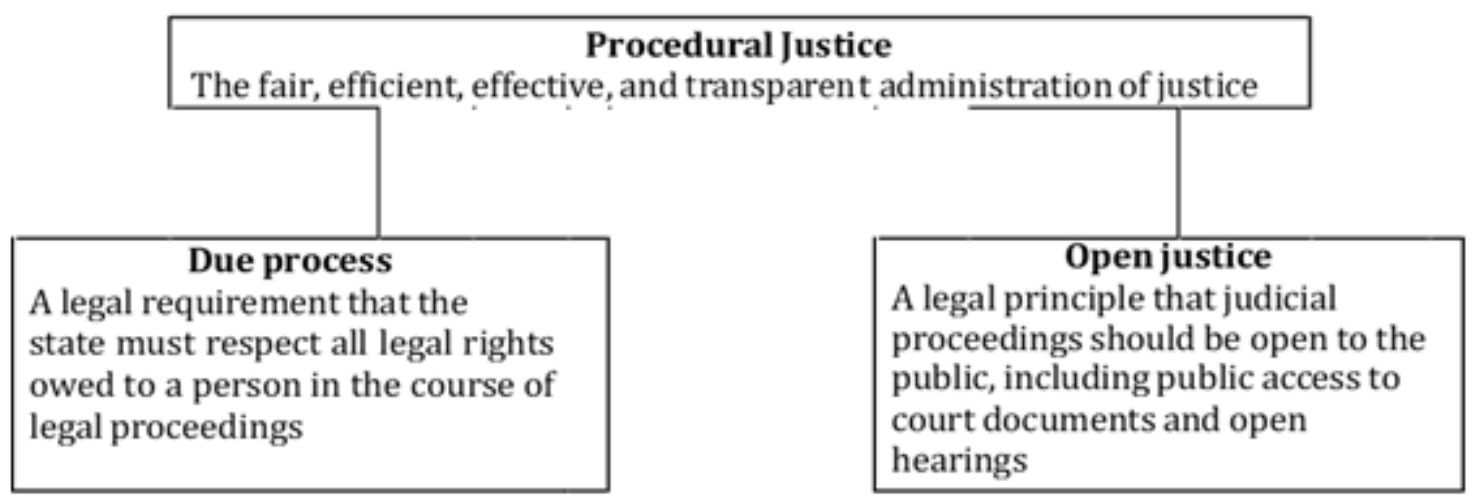

Figure 1. Dispute Resolution Approach

Studies by Tyler (1988) on citizen interaction with legal authorities revealed seven underlying dimensions to perceptions of judicial fairness: opportunity for representation, quality of decision, honesty, ethicality and motivation of the authorities, lack of bias of authorities, and opportunities for correction. The constitutional provisions of most African countries have not been applied to Tyler's standard to help deal exhaustively with the challenges of post-election conflict resolution on the continent. The delay of justice for election petitions serve to undermine the search for electoral justice. According to Omotola (2009), in Nigeria, till date, some election petitions filed following the disputed general election in 2007 are still ongoing. However, in countries like Ghana and South Africa, the courts have been helpful to curb election disputes degenerating in violence by speedily and professionally disposal of election petitions and complaints. This exemplary conduct of the judicial activism was witnessed in Kenya, where the Supreme Court of Kenya tactfully and professionally handled the election petition filed by the opposition candidate, Raila Amolo Odinga following the disputed 2017 presidential elections.

This is corroborated by a study conducted by Frempong (2010). According to Frempong, the role of the judiciary has been most beneficial in resolving election disputes. The judiciary in Ghana has asserted its independence and has treated most election-related petitions with alacrity. Such cases included: the fixing of the 7th December Election Day, the controversy over the use of thumb-printed voter identification cards in 2000, and the creation and demarcation of constituency boundaries. Notable of such judicial response is the tact and professional manner in which the Supreme Court of Ghana handled the 2012 election petition filed by the then opposition, the New Patriotic Party following the disputed election results in the 2012 presidential elections. This underscores the need for the elements of procedural justice, open justice and due process to be present in the overall electoral legal architecture. The impartial and fair application of this triangular constitutional, legislative and regulatory approach by the judiciary towards resolution of election related dispute could have the impact of minimising post electoral conflict.

\subsection{Electoral Governance Approach}

Election Management Bodies (EMBs) are responsible of the administration of the election. Additional duties may also be bestowed on these bodies to act as arbiter of election disputes. The role of the EMBs as arbiters towards dispute resolution could be adjudicatory where it acts as a judicial body or conflict preventive through effective stakeholder management, consensus building and electoral reform programmes where the EMB acts in the capacity as an administrator of elections. But in both instances, the EMB must be neutrally professional and independent. Public confidence in the election dispute resolution process is two-fold. It requires trust in the independence and impartiality of arbiters who decide cases, as well as trust in the process through which the decisions are made (Gibson et al., 2003). This segment of the article deals with how election management bodies in Africa could adopt and apply administrative procedures to prevent and manage electoral disputes from filing to disposition. However, some election management institutions acting quasi-judicial capacity are often unprepared to apply the legal standards necessary to protect procedural justice in competitive electoral environment (IFES, 2016). This could be that these institutions do not have the judicial infrastructure in place to implement procedure in a manner that protects procedural justice rights of aggrieved stakeholders in election management. 
Article 14 of the International Covenant on Civil and Political Rights (ICCPR) and Article 10 of the Universal Declaration of Human Rights (UDHR) guarantee the right to due process. This right to due process is well recognized in traditional court systems, but is an equally essential right in the adjudication of electoral disputes. It must be respected regardless of whether an election complaint or irregularity is dealt with administratively. This highlights the fact that the competence of the EMB to consider disputes will be determined by the nature of the dispute itself, and a distinction must be made between what are essentially administrative issues, and issues that impact fundamental rights. Issues of administrative nature in election administration may well be handled by an EMB or other administrative body may be sufficient. However, if rights are violated, then, the state is obligated to investigate and, if a violation is determined, provide a remedy. The issue of whether an electoral contestant appears on the ballot, for example can illustrate this. Being denied access to a ballot is a fundamental human rights issue, but if you are on the ballot, the sequence of the contestant's position on the ballot is an administrative issue that must be handled by the EMB through a transparent process.

Some countries in Africa have either a permanent or mixed model for election dispute resolution. In South Africa, the Electoral Commission Act (No 51 of 1996) empowers the electoral commission to adjudicate disputes that may arise from the organisation, administration and conduct of elections, provided such disputes are primarily of an administrative nature. In the discharge of this dispute resolution function, the Electoral Commission act as a tribunal and its decisions are subject to review by the Electoral Court. Again, in Kenya, the Independent Electoral and Boundaries Commission (IEBC) is responsible for resolving electoral disputes, except election petitions and disputes subsequent to the declaration of election results (IEBC Act, 2016). However, the Political Parties Disputes Tribunal (PPDT) in Kenya, has jurisdiction over disputes between political parties, party members, candidates, and coalitions, as well as appellate jurisdiction regarding the decisions of the Registrar of Political Parties and disputes arising out of party primaries (Political Parties (Amendment)(No.2) Act, 2016. This requires electoral governance institution to be professional, independent to implement effective dispute resolution system for correct interpretation and application of electoral laws and procedures. In the absence of this, electoral dispute resolution may be nothing more than mere facade, with limited or no actual effect in conflict resolution.

A more fundamental issue relates to the question of professional and impartial application of dispute resolution laws by the EMBs. It is unclear whether the EMBs would be considered independent given that they are also a stakeholder to administer the elections. According to Shola (2015), while laws are important to shape and reshape electoral contests and provide the basis for litigation in the event of violations, no law can, on its own, guarantee fair play in the conduct of elections. UNHRC General Comment 32 (2000: p.33) states that "an EMB that administers an election and then adjudicates disputes related to the administration of that election may not appear impartial to a reasonable observer". This means that much depends on the capacity, neutrality and professionalism on the election management body to conduct the elections in accordance with international standards of democratic elections and established domestic laws and regulations. It is therefore, important to underscore that, application of the legislative approach to election dispute resolution may not necessarily guarantee credible and incident free elections. For example, the Ghana Electoral Commission which is globally noted to conduct credible competitive elections has no legal mandate to adjudicate on election related dispute. The Commission has since 1993, adopted an administrative machinery using the electoral cycle and stakeholder management approach to mitigate or prevent electoral dispute through the institution of the Inter-party Advisory Committee (IPAC).

The IPAC, is platform created by the Electoral Commission of Ghana to brings together political parties and other critical stakeholders to dialogue on critical matters that affect election administration with the aim of deepening the electoral system of Ghana. The platform improves cooperation between the commission and registered parties on all electoral matters. This seeks to handle disputes that may threaten the conduct of elections in Ghana. This election dispute resolution mechanism has also been adopted in some African countries. For example, the Independent Electoral Commission of South Africa established the Party Liaison Committee as an important political co-operation mechanism which has contributed substantially to the prevention of electoral violence. This electoral governance approach to preventing and managing electoral dispute should permeate through the electoral cycle and must involve the use of matrix of inclusion through stakeholder management.

\subsection{Electoral Cycle Approach}

Elections are very complex, dynamic and involve high-stake processes. As a result, election administration is not an event but a process that requires continuous perfection and improvement. Studies show that a comprehensive program to support democratisation and good governance through elections and to reduce tensions around election time should focus on long run and not on short term interventions (Fischer, 2002; Höglund, 2006; 2009). An electoral cycle is a visual planning and training tool that aims to support electoral actors to acknowledge the cyclical nature and the various challenges faced in electoral processes (IDEA, 2006). The electoral cycle 
appreciates elections as continuous processes rather than isolated events (ACE Electoral Knowledge Network, 2011). According to Brancati and Snyder (2010), decsions by electoral institutions of what could be done in order to guarantee free and fair elections and to minimise conflict has to include the entire electoral cycle. This means that effective and transparent involvement of stakeholders in the implementation of electoral cycle helps to mitigate disputes and conflicts. To this end, to avoid suspicion and mistrust, election management bodies must involve stakeholders in all phases of the electoral project. Figure 2 demonstrates the electoral cycle approach to election dispute resolution.

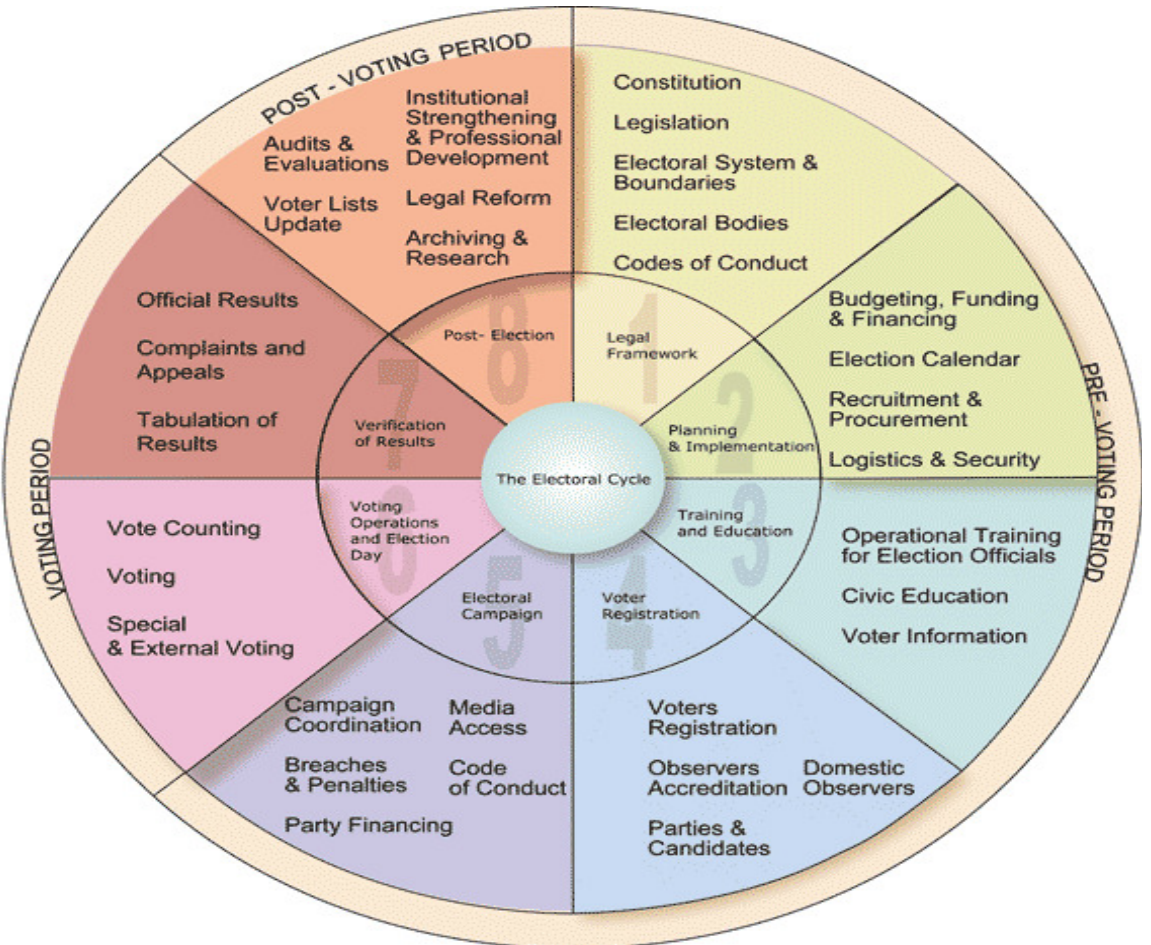

Figure 2. The Electoral Cycle Approach

Fischer (2002) distinguishes five different types of electoral related violence: (1)Identity conflict during the registration process when citizens cannot establish or re-establish their official recognition as voters, (2) Campaign conflicts as rivals seek to disrupt the opponents' campaigns, intimidate voters and candidates, and use threats and violence to influence participation in the voting, (3) Balloting conflict on election day when rivalries are played out at the polling station, (4) Disputes over election results and the inability of judicial mechanisms to resolve disputes a fair, timely, and transparent manner, and (5) Representation when elections are organized as 'zero sum' events and 'losers' are left out of participation in governance. This requires electoral governance institutions to put in place mechanisms to resolve electoral disputes throughout the entire electoral cycle. These mechanisms should provide possibilities to handle election related complaints and disputes at any phase of the electoral process in an efficient and independent way, since compared to the legislative approach, delay in the procedures can affect the resolution process

\section{Stakeholder Management Approach}

The stakeholders of an election management body are individuals, groups and organizations that have an interest in the electoral process. These stakeholders are directly affected by the activities, policies and practices of the EMB. Stakeholder engagement process is an integral part of sustainable election governance (Akwei, 2018). Most studies on electoral violence tend to focus on during election and post-election activities. Yet political parties, contesting candidates, security forces, civil society and the media remain key stakeholders in the electoral process. The actions of these groups play persuasive role on the minds of the electorate. Political parties and the followers for instance, can destruct the electoral process in the run-up to the elections, during the elections and after the elections. Stakeholder management is therefore a critical tool to build confidence in the election management bodies.

Voter and public confidence in elections has an effect on the legitimacy of institutions and the quality of democratic representation. Research indicates that confidence in governing institutions, especially procedural fairness, promotes regime support and compliance of public policies (Braithwaite and Levi 1998; Tyler 2001). Thus, such perceptions of the election process are critical for the maintenance of peace and order in a democratic state. Other studies have suggested that confidence in election administrators is related to confidence in election 
outcomes (Barrientos del Monte (2008). According to Krevel (2009), the attitude of election management bodies (EMBs) towards critical stakeholders in the electoral process helps influence individual perceptions of election quality and political participation thereby reducing tension in electoral contest. In pursuit of this assertion, the role to be ascribed to civil society, political parties and the media in support of Electoral Management Bodies in preventing electoral dispute remains unquestionable. This segment of the article seeks to assess stakeholder engagement framework for electoral governance institutions in Africa as a dispute resolution mechanism to create, communicate, deliver, and exchange sustainable strategies to mitigate election violence. Figure 3 shows some critical election stakeholders.

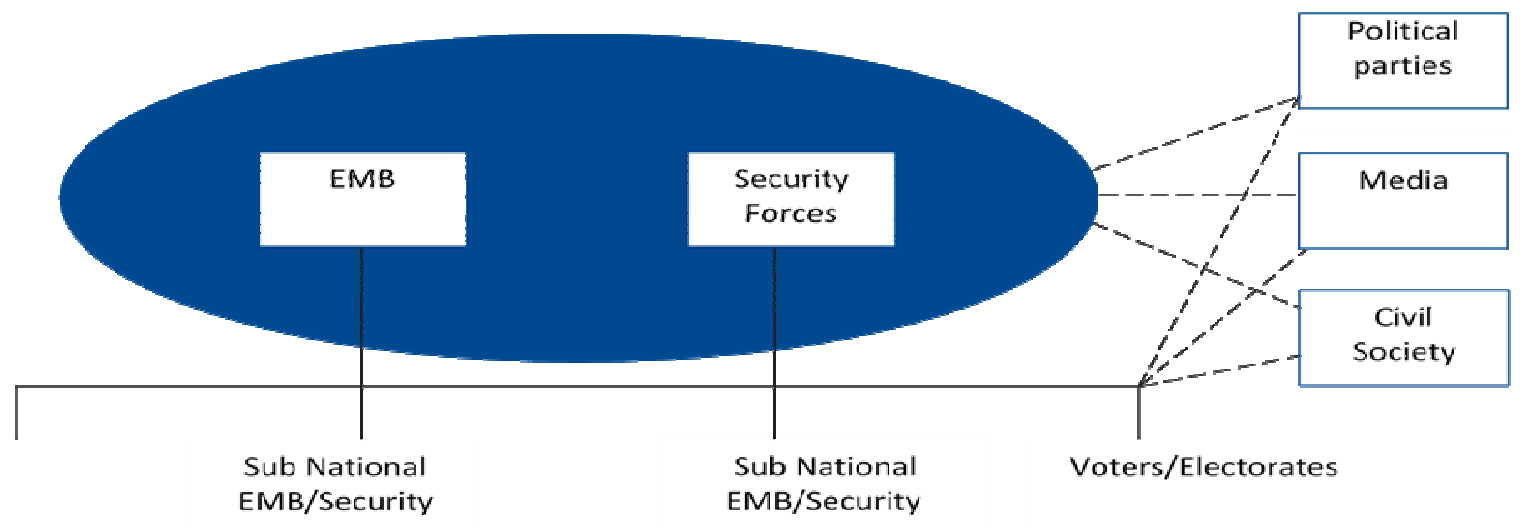

Figure 3. Electoral Stakeholders Matrix

A study by the United States Institute of Peace assessed the efficacy of different prevention strategies to reduce electoral violence. The study proved that prevention strategies do work in reducing violence. A particular measurable indicator of the study suggests that civil society programs seem to be limited in their efficacy despite its theoretically compelling logic as an effective conflict prevention tool (Claes, 2016). Claes suggests that stateled programs in the form of security enhancement and improving election administration and management offer the most effective means to reduce electoral violence. In contrast, Höglund and Jarstad (2010) argue that civil society organizations (CSOs) can initiate successful programmes to limit election violence. According to the researchers, civil society's adoption of acceptable codes of conduct during elections can help bring together contesting candidates to support peaceful election. Adebayo (2016) argues that training and agreement among media organizations for journalists on best practices for 'conflict-sensitive reporting' can help reduce election violence. The integration of civil society and the media to participate in the electoral process by way of monitoring and reporting of election day activities, including documenting acts of election day violence and intimidation can reduce electoral tension and violence. According to Oduro (2012), the involvement of Coalition of Domestic Election Observers (CODEO) in the Ghanaian electoral process has shown to be a successful example of CSO-generated initiative to combat electoral violence.

Studies suggest that several types of stakeholder typological strategies for preventing electoral violence have the potential to successfully reduce the risks of violence (Claes, 2016). The prevalence of electoral violence on the African continent suggest that some stakeholder initiatives have proved not to be workable in all countries. It should be noted that no single set of programme exists that will prove effective across all countries. Different historical, institutional and enthno-political environment require that strategies be tailored to meet the needs of particular countries circumstances. Table 3 proposes a typology of electoral violence prevention strategies encountered both in literature and field research. 
Table 3. Typology of programs for the prevention of electoral violence

\begin{tabular}{|c|c|c|c|c|}
\hline & \multicolumn{2}{|c|}{ Civil society-initiated programs } & \multicolumn{2}{|c|}{ Government-initiated programs } \\
\hline $\begin{array}{l}\text { Election } \\
\text { technical } \\
\text { assistance }\end{array}$ & 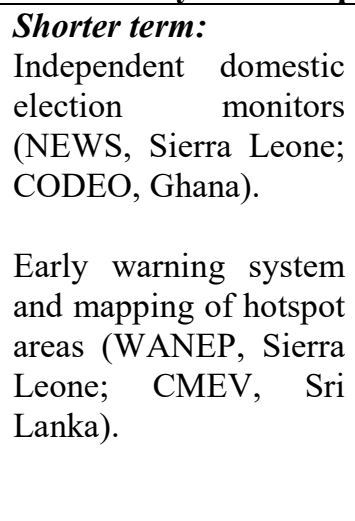 & $\begin{array}{l}\text { Longer term: } \\
\text { Journalist/media } \\
\text { training on election } \\
\text { violence-sensitive } \\
\text { reporting (AFSC, } \\
\text { Kenya \& } \\
\text { Sierra Leone). }\end{array}$ & $\begin{array}{l}\text { Shorter term: } \\
\text { Inviting } \\
\text { international } \\
\text { election monitors } \\
\text { (UN, EU, Carter } \\
\text { Center, etc.). } \\
\text { Civic education of } \\
\text { rules and processes } \\
\text { for casting ballots } \\
\text { and running for } \\
\text { office. }\end{array}$ & $\begin{array}{l}\text { Longer term: } \\
\text { Strengthening } \\
\text { election } \\
\text { management body. } \\
\text { Constitutional } \\
\text { change/reform of } \\
\text { electoral laws } \\
\text { (Kenya 2010). } \\
\text { Post-election dispute } \\
\text { resolution } \\
\text { mechanisms }\end{array}$ \\
\hline $\begin{array}{l}\text { Social peace } \\
\text { building }\end{array}$ & $\begin{array}{l}\text { Shorter term: } \\
\text { Peace messaging } \\
\text { during campaign } \\
\text { (ActionAid, Sierra } \\
\text { Leone \& Nigeria; } \\
\text { NICE, Malawi). } \\
\text { Civic education of } \\
\text { rights, laws, and } \\
\text { regulations regarding } \\
\text { election (SEAG, Sierra } \\
\text { Leone; NICE \&MESN } \\
\text { Malawi) }\end{array}$ & $\begin{array}{l}\text { Longer term: } \\
\text { Youth peace } \\
\text { programming and } \\
\text { education (PAMBIO, } \\
\text { Kenya; Amani clubs, } \\
\text { Kenya). } \\
\text { Fostering } \\
\text { intercommunity } \\
\text { dialogue (PeaceNet, } \\
\text { Kenya) of } \\
\text { Sensitization } \\
\text { gendered nature of } \\
\text { electoral violence } \\
\text { (VAWIE). }\end{array}$ & $\begin{array}{l}\text { Shorter term: } \\
\text { Training and } \\
\text { stationing of law } \\
\text { enforcement for } \\
\text { election security } \\
\text { (UNDP, Kenya, } \\
\text { Malawi, Sierra } \\
\text { Leone). } \\
\text { Establishing peace } \\
\text { platforms and local } \\
\text { peace committees } \\
\text { for the election } \\
\text { (MPLC, Malawi; } \\
\text { Uwiano, Kenya }\end{array}$ & $\begin{array}{l}\text { Longer term: } \\
\text { Broad ethnic } \\
\text { integration and } \\
\text { promotion of } \\
\text { tolerance (NCIC \& } \\
\text { NSC, Kenya). } \\
\text { Land/resource } \\
\text { conflict resolution } \\
\text { (NLC, Kenya). }\end{array}$ \\
\hline $\begin{array}{l}\text { Political party } \\
\text { engagement }\end{array}$ & $\begin{array}{l}\text { Shorter term: } \\
\text { Authoring peace } \\
\text { pledges for parties and } \\
\text { candidates to sign } \\
\text { (PAC, Malawi). } \\
\text { Provide support and } \\
\text { resources for female } \\
\text { candidates } \\
\text { Sierra } \\
\text { Leone). } \\
\begin{array}{l}\text { Involve } \\
\text { candidates political } \\
\text { and parties in field } \\
\text { programs }\end{array}\end{array}$ & $\begin{array}{l}\text { Longer term: } \\
\text { Training for political } \\
\text { parties manifesto } \\
\text { on issue-based } \\
\text { development } \\
\text { and party } \\
\text { campaigning } \\
\text { (CMD-Kenya). } \\
\text { Recruit youth peace } \\
\text { wing } \\
\text { members in programs (ActionAid, } \\
\text { Sierra Leone). }\end{array}$ & $\begin{array}{l}\text { Shorter term: } \\
\text { Establish } \\
\text { enforceable } \\
\text { “'“code of conduct” } \\
\text { for } \\
\text { parties (PPRC, } \\
\text { Sierra } \\
\text { Leone; } \\
\text { Malawi). } \\
\text { Encourage parties' } \\
\text { participation in } \\
\text { peace } \\
\text { platforms and local } \\
\text { committees } \\
\text { (MPLC, Malawi; } \\
\text { Uwiano, Kenya). }\end{array}$ & $\begin{array}{l}\text { Longer term: } \\
\text { Hate speech } \\
\text { monitoring, } \\
\text { enforcement of hate } \\
\text { speech } \\
\text { laws, and public } \\
\text { sensitization } \\
\text { of acceptable } \\
\text { political } \\
\text { discourse (NCIC, } \\
\text { Kenya). }\end{array}$ \\
\hline
\end{tabular}

The typology suggests that electoral violence prevention strategies can be categorized into three dimensions:

1. The first typology deals with whether the program is civil society-initiated or government-initiated;

2. The second typology is evaluating whether the program is aimed at improving technical and operational aspects of the election, aimed at promoting peace, or aimed at engaging political parties and their candidates; and

3. The third typology focus on assessing whether a program should be short term and focus on the elections or it should be long-term to last across multiple electoral cycles.

The first dimension is focused on which stakeholder initiates a particular program with the tag between whether civil society or the government initiates violence prevention programmes. Both civil society and government are critical stakeholders of an electoral process. Studies on mediation systems tend to involve various types of stakeholders in an inclusive approach (Akwei, 2008). It is therefore essential to ensure that an 
inclusive approach prevails within mediation systems. According to Taylor (2018), government sponsored peace platforms and local peace committees have the potential to effectively coordinate CSO programs at the local level to avoid program redundancies. This is because CSOs are particularly active in setting up warning mechanisms for elections (Crouzel, 2014). While the CSOs may be constrained by resources to discharge their duties effectively, the state may support them in that regard.

As a result, some conflict prevention initiatives instituted by some African countries have increased the call for extensive stakeholder engagement approach to preventing or mitigating electoral dispute. For example, the Multiparty Liaison Committees in Malawi, although state-sponsored, have proven to be an effective platform to encourage collaboration between incumbent and opposition parties as well as CSOs (Mapuva, 2013). In the South African case, the Party Liaison Committees established by the Independent Electoral Commission, underlines the importance of including political parties in the management of electoral conflicts. Kenya, in 2017, initiated several peace building programs focusing on electoral violence prevention after various calls on both civil society organizations and state agencies to integrate effort to promote peaceful elections. The establishment of the National Cohesion and Integration Commission (NCIC) and the Multi-Sectoral Forum (MSF) to encourage, civil society, political parties and interreligious cooperation and dialogue to ensure peaceful election environment has yielded fruits. Sierra Leone's violence prevention efforts in 2008 in the form of the National Early Warning System (NEWS) programme has also incorporated several organizations in implementing violence prevention programs. The Amatora mu mahoro project ('Elections in peace') in Burundi is another example of a multi-stakeholder real-time mapping initiative that charts the electoral climate in a given territory. It is based on a rigorous methodology that reports verified occurrences of peace activities and incidents of election violence gathered by over 450 monitors across Burundi, thus offering comprehensive and reliable data for violence mitigation efforts. The pioneering example of Ghana's Inter-Party Advisory Committee (IPAC) has been centripetal for stable electoral environment for the country since 1994.

Studies demonstrates that violence can be caused by both weak election management institutions (Eklit and Reynold, 2002) and local resource conflicts between rival groups (Taylor, 2018). This emphasises the importance of the second typological dimension of violence prevention focused on interventions geared towards building technical competences for the election administrators to organise credible and transparent elections, building capacities for the communities that may be affected by election violence, or the political parties and candidates to prevent potential misunderstanding of the electoral process that can generate electoral conflict. Birch and Muchlinski (2017) refer to this violence prevention programme as capacity building strategies and attitude transforming strategies. This strategy tends to strengthen those institutions that manage elections, such as the electoral commission and election observation teams, and those strategies that attempt to inhibit violence through grassroots stakeholder mediation, intercommunity dialogue, and engagement with potential perpetrators and victims of violence. This strategy offers strong justifications for use in volatile electoral environment. For example, a civic education program may be used to both communicate the procedures and rules for voting and engage in peace messaging and stakeholder meetings in communities that are prone to violence.

The third typology considers strategies that engage stakeholders of the electoral process for long term. This calls for building effective long-term alliance and collaboration between election management bodies, civil society and political parties. Studies show that facilitating long-term inter-community dialogue may be better put in the hands of civil society actors that do not face accusations of being affiliated with any political party (Akwei, 2018; Mapuva, 2013; Taylor, 2018). This is where there seem to be differences between the Malawian Multiparty Liaison Committees and the Kenyan National Cohesion and Integration Commission (NCIC) and the Multi-Sectoral Forum (MSF). Although, there are some similarities in the two models of conflict prevention programmes, there exist critical differences in the design of the programmes. This difference should serve as a useful lesson for other countries on the continent.

In particular, the success of Malawi's violence prevention programs in incorporating the political candidates as active stakeholders serves as a key difference of practical importance. Whereas politicians were mainly sidestepped in Kenya's violence prevention programs, multiple programs in Malawi made considerable efforts to ensure that both national and local political candidates were incorporated into pre-election peace programs and subsequent mediation efforts. The time allocated by state actors in implementing the third strategy is of particular importance. According to Taylor (2018), while certain activities in the electoral cycle such as civic education campaigns, training of election monitors on campaign rules require shorter time frames close to the date of the election, other programs must permeate through the entire election cycle to be successful. This means that lack of sustainable funding to conflict prevention initiatives may render the programmes ineffective and abortive.

Beyond these three identifiable typologies, it is essential to also involve the legitimate authorities within a given society. In most countries, religious and traditional actors who are listened to and respected within their communities are often solicited to prevent or appease conflicts. This model takes the shape of public awareness campaigns against electoral violence. In Senegal, religious leaders, opinion-makers and social figures such as 
traditional wrestlers have been used as messengers of peace (LAREG, 2011). Mediation systems that already exist and are effective can also be mobilised within the electoral framework. Such was the case of the bashingantahe in Burundi, who are public figures endowed with moral authority and seen as 'the wise'. They are the heirs to an informal system that manages local conflicts and have been involved as 'peace agents' at election times. These bashingantahe have been accredited by the Independent National Electoral Commission as election observers and mediators when electoral disputes occur.

The multi stakeholder management of conflicts is fundamental to keeping electoral processes peaceful. In Nigeria, Liberia and Senegal, civil society election situation rooms were created to gather a broad coalition of CSOs during elections so they could pool resources and better co-ordinate their actions to identify, prevent and mitigate electoral tensions. These election situation rooms tend to work in partnership with EMBs and relevant state authorities in order to mobilise the most appropriate responses (OSIWA, 2012). Procedures aimed at limiting and containing electoral violence can only be effective if they form part of the institutionalisation of the electoral system as a whole. However, no matter how essential this focus on the electoral system is, it is not sufficient to ensure the stability of electoral processes. The stability of the electoral process is narrowly conditioned by the implementation of democratic governance, which is a vehicle for multi-stakeholder interactions, accountable public action, and ensuring legitimacy among the electorate.

\section{Conclusion}

In the past two decades, competitive elections have become a normative principle to legitimize political leaders in many African countries. Credible elections in some countries like Ghana, Mauritius, and South Africa, have helped consolidate democratic institutions and enhanced prospects for greater economic and political development. In other countries, such as Liberia and Sierra Leone, credible elections have paved way for national reconciliation and a return to democratic rule after decades of armed conflict and civil war. On the other hand, flawed elections in countries such as Kenya and Zimbabwe have led to violence, loss of life, and destruction of property, and have seemed to erode the democratic dividends of elections. Studies show that in Africa, some of the conflicts and violence that occur around elections are as the result of a breakdown of the electoral process (Lopez-Pintor, 2000). This violence is somehow created by the actions and inactions of unprofessional electoral governance institution, ineffective and unfair legislative and adjudicatory system and the lack of effective involvement of critical stakeholders in the electoral process. Electoral dispute resolution (EDR) is a critical part of the electoral process that requires greater attention among election practitioners and policy makers. While there remain few international and domestic framework that shed light on EDR, the general obligations related to the right to an effective remedy, the right to a fair public hearing and concept of broadbased inclusion in the electoral process remain strong basis to move the frontiers of election administration in Africa. This article set out to evaluate changes that could be made to strengthen electoral management and use it as fundamental concept to prevent electoral conflict in Africa.

The analysis demonstrates that the institutions that are responsible for fair application of electoral laws (the courts) and those responsible to manage elections (EMBs) often fail to do so in manner that gains the acceptance of all stakeholders' due lack of independence and neutrality. This shows that the higher the performance of EMBs and the Judicial bodies, the lower the rate of electoral violence and the lower the performance in terms of the independence and credibility of these institutions, the higher the rate of electoral violence. This discovery indicates that the level of independence and non-partisanship execution of electoral administration is profoundly connected with the nature of electoral disputes and viciousness.

A wide range of suggestions for improvements have been made. These suggestions could be of great benefit to most Africa countries that are committed to entrench democracy by using elections as a central tool. The study proposes that an active participation and involvement of critical stakeholders such as the media, legislative bodies, political parties and civil society in the electoral process during an electoral cycle and conflict management processes should become the central agenda for African countries in mitigating conflict that occasionally surrounds elections. This means that an action-oriented dialogue among election stakeholders is critical for building an inclusive electoral management model. The study recommends that election management bodies on the African continent should consider establishing similar structures, which would serve as avenues of consensus building among EMBs, political parties and the electorate to forestall electoral disputes. The findings from this study should be considered as starting point lessons for practitioners and policy makers seeking to explore strategies to improve electoral democracy and the conduct of incident free elections. It is hoped that this study will contribute to further identifying and adapting the most effective programmes to reduce electoral violence in many developing countries. Additional study is recommended to further identify why similar conflict resolution programmes have varying levels of success in different electoral environments.

\section{References}

Aaken, Anne (2007). Independent Electoral Management Bodies and International Election Oberver Missions- 
Any Impact on the Observed Levels of Democracy? A conceptual framework.

Abuya, Edwin (2009). Consequences of a Flawed Presidential Election, 29 LEGAL STUDS. 127.

ACE Electoral Knowledge Network, "The Electoral Cycle Approach". [Online]. Available: http://aceproject.org/ace-en/focus/focus-on-effective-electoral-assistance/the-electoral-cycle-approach. [Accessed: July 8, 2019].

Adebayo, Joseph Olesegun (2016). "Fostering Non-Violent Elections in Africa Through Conflict Sensitive Reportage of Elections.” African Security Review 25(3): 303-315.

African Charter on Human and Peoples' Rights (1981). Adopted 27 June 1981, entered into force 21 October 1986) (1982) 21 ILM 58 (Banjul Charter - AfCHPR).

African Union Declaration on the Principles Governing Democratic Elections in Africa (2002). Adopted at the 38th Ordinary Session of the Organization of African Unity, 8 July 2002, Durban, South Africa, AHG/Decl.1 (XXXVIII), 2002

Ajayi, Ola (2009). Appeal Court sacks Senator Omisore, Vanguard.

Akwei, C. (2018). "Mitigating Election Violence and Intimidation: A Political Stakeholder Engagement Approach", Politics and Policy, vol. 46, pp.472-504.

Atkeson, Lonna Rae, Saunders, Kyle L. (2003). "The Effect of Election Administration on Voter Confidence: A Local Matter?” Political Science \& Politics, pp. 657-658.

Armah, A K. (2008). 'African elections, ending the violence'. New African 481. [Online] Available: http://0web.ebscohost.com.innopac. wits.ac.za/ehost/results?vid=2\&hid=9\&sid=5e0958f0-f0a4-4cec-afb9b [Accessed: July 8, 2019].

Baregu, M. (2009). 'Democracy is not enough: The legitimacy crisis and the resurgence of military coups inAfrica', Paper presented at EISA's fourth Annual Symposium, Johannesburg, 17-18 November 2009.

Barrientos del Monte, Fernando. (2008). "Confianza en las elecciones en América Latina.” Prepared for delivery at the Seminario de Investigación del Àrea de Ciencia Política y de la Administración, Universidad de Salamanca, November.

Bekoe, A. Dorina (2010). "Trends in Election Violence in Sub-Saharan Africa," United States Institute of Peace, Peace Brief, no. 13.

Birch, Sarah \& David Muchlinski (2017). "Electoral Violence Prevention: What Works?” Democratization.

Braithwaite, Valerie, and Margaret Levi (1998). “Trust and Governance”, New York: Russell Sage Foundation.

Brancati, D \& Snyder, JL (2010). "Time to kill: the impact of election timing on post-conflict stability", Draft Paper, viewed 8 February 2011, <http://brancati.wustl.edu/Time2Kill.pdf $>$.

Carter Center (2011). Final Report: Presidential and Legislative Elections in the Democratic Republic of Congo.

Claes, Jonas, (2016). "Election Peace: Violence Prevention and Impact at the Polls", Washington, DC: United States Institute of Peace.

Commonwealth Secretariat (2005). "Commonwealth Expert Team Final Report: Sri Lankan 2005 Presidential Election".

Calingaert, Daniel (2006). "Election Rigging and How to Fight It", Journal of Democracy, vol.17, pp.138- 147.

Crouzel, Ivan (2014). "Elections and the Risk of Instability in Africa: Supporting Legitimate Electoral Processes", South African Institute of International Affairs.

Duodu, I. (2010). "Elections in Africa: A terrifying prospect" Pambazuka News in The Independent [Online] Avaliable: http://www. theindependent.co.zw, pp.19:20. November 25, 2010

Elklit Jørgen, Reynolds, Andrew (2002). "The Impact of Election Administration on the Legitimacy of Emerging Democracies: A New Comparative Politics Research Agenda", Commonwealth \& Comparative Politics, vol.2, no.40, pp.86-119.

Emmert, Frank et al. (2007). "Trouble Counting Votes? Comparing Voting Mechanisms in the United States and Selected Other Countries”, 41 CREIGHTON L. REV. 3, pp.24-6.

European Union (2011). "Election Observation Mission Final Report: Uganda 2011."

Fandrych, S (2003). "Short report on the Regional Conference on the Prevention and Management of ElectionRelated Conflict in the SADC Region", Universidade Católica de Angola and Friedrich Ebert Stiftung.

Fischer, J (2002). "Electoral conflict and violence: a strategy for study and prevention", International Foundation of Electoral Systems white paper, Friedrich Ebert Stiftung, Washington DC.

Freeman, Mark (2006). Truth Commission and Procedural Fairness 134.

Frempong, A.K.D (2008). "Innovations in electoral politics in Ghana's Fourth Republic": an analysis, In Ciska Raventós (ed), Democratic innovation in the South: participation and representation in Asia, Africa and Latin America, Buenos Aires.

Ghana, (1992). The Constitution of the Republic of Ghana.

Gyima-Boadi, Emmanuel (2008). "Managing Electoral Conflicts: Lessons from Ghana”, Journal of Election and Conflict Management in Africa, pp.101-114.

Gibson, James L. Caldeira Gregory A., and Spence, Lester Kenyatta (2003). "Measuring Attitudes toward the 
United States Supreme Court”, Journal of Political Science, pp.354.

Hammar A (2009). "Disrupting Democracy"? Altering Landscapes of Local Government in Post-2000 Zimbabwe, Discussion Paper No. 9, Destin.

Hammar A (2008). "New Deal for Zimbabwe - A framework for change?", Paper presented at a seminar on the political future of Zimbabwe co-hosted by the Swedish Institute of International Affairs, Forum for Living History \& Nordic Africa Institute, Stockholm.

Hansen, Thomas Obel (2009). "Political Violence in Kenya-A Study of Causes, Responses, and a Framework for Preventative Action".

Harris, David (1999). "From "Warlord" to "Democratic" President: How Charles Taylor Won the 1997 Liberian Elections", Journal of Modern Africa Studies, vol. 37, pp. 431-441.

Hasen, Richard (2005). "Beyond the Margin of Litigation: Reforming U.S. Election Administration to Avoid Electoral Meltdown”, 62 WASH. \& LEE L. Review no. 937, pp. 973-984.

Höglund, K (2009). "Electoral violence in conflict-ridden societies: concepts, causes and consequences", Terrorism and Political Violence, vol. 21, no. 3, pp. 417.

Höglund, K (2006). "Electoral violence in war-ravaged societies: The case of Sri Lanka", paper prepared for the workshop on Power-Sharing and Democratic Governance in Divided Societies, Centre for the Study of Civil Wars, August 21-22, 2006.

Höglund, K., Jarstad, Anna (2010). "Strategies to prevent and manage electoral violence: considerations for policy", ACCORD Policy \& Practice Brief 1.

IDEA (2006), Electoral Management Design: The International IDEA Handbook International Federation for Electoral Systems (2012) "Kenya Elections: Building Peaceful, Credible Political Process." Washington, DC.

IFES Sri Lanka EIA (2016). "Due to the absence of codified procedures...there was no common process used by the election complaints centers." Excerpts from IFES Electoral Integrity Assessments

IFES Myanmar EIA (2015) "There is no formal mechanism for filing prelection/campaign complaints, and the Election Day complaints process remains unclear."

Independent Electoral and Boundaries Commission Act (2016), S. 4; Rules of Procedure on Settlement of Disputes (2012) rul. 4.

International Peace Institute (2011). "Elections in Africa: Challenges and Opportunities".

Icelandic Human Rights Centre (2017). "The Right to Due Process". [Online] Available: http://www.humanrights.is/en/human-rights-educationproject/human-rights-concepts-ideas-andfora/substantive-human-rights/the-right-to-due-process. [Accessed July 8, 2019].

Jacobs, Andreas (2011): "Nairobi Burning. Kenya's Post-Election Violence from the Perspective of the Urban Poor", PRIF Report No 110, Frankfurt a.M.

James Lee, R. (1995). "Democracy and International Conflict”. Columbia: University of South Carolina Press.

Jinadu, Adele L (1997). "Matters Arising: African Elections and The Problem of Electoral Administration”, African Journal of Political Science, vol. 2, no. 1, pp.1-11.

Kenya (2008). The Constitution of Kenya Review Act, Cap. 3A § 2, Nairobi, Government Printer.

Kenya (2016). The Independent Electoral and Boundaries Commission (IEBC) Act, 2016.

Kenya (2016). Political Parties (Amendment)(No.2) (2016). Act, No. 21 (2016) Kenya Gazette Supplement No.112.

Kriger, N. (2011). "Foreign aid dilemmas under Zimbabwe's inclusive government" [Online]. Available: http://www.solidaritypeacetrust.org/1092/foreignaid-dilemmas. [Accessed July 10, 2019].

Kristina, Murphy (2017). "Procedural Justice and its Role in Promoting Voluntary Compliance" in Peter Drahos (Ed.) Regulatory Theory: Foundations and Applications, ANU Press, vol. 43.

Khadiagala, G. (2009). "Reflections on the Causes and Consequences of Election Violence in Africa", Paper presented at EISA's fourth Annual Symposium, Johannesburg, 17-18 November 2009.

Krevel, Yann (2009). Election Management Bodies and Public Confidence in Elections: Lessons from Latin America, University of New Mexico, IFES fellowship of Democracy studies.

LAREG (2011). "Violence in the electoral processes of Senegal between 2000 and 2011", Études et travaux du LAREG $n^{\circ} 1$, Dakar.

Lindberg, S I. (2008). “Democratization by Elections: A New Mode of Transition?". Paper presented at Duke University, 27 October 2008, Department of Political Science, University of Florida.

López-Pintor, Rafael (2000). "Electoral Management Bodies as Institutions of Governance", Bureau for Development Policy United Nations Development Programme, pp.1-251.

Makumbe J (2009). "Theft by Numbers; ZEC's Role in the 2008 Elections", Defying the Wind of Change.

Mapuva, Jephias (2013). "Elections and electoral processes in Africa: A gimmick or a curse?”, African Journal of History and Culture, Vol.5, no.5, pp.87-95.

Masunungure, EV (2009). "Defying the Winds of change”, Konrad Adenauer Foundation. 
Melber, H (2002). Zimbabwe's Parliamentary Elections 2002, Evidence, Lessons and Implications, Uppsala.

Mendes and Anderson; Llewellyn, Morgan H., Thad E. hall and R. Michael Alvarez (2009). "Electoral Context and Voter Confidence: How the Context of an Election Shapes Voter Confidence in the Process", Caltech/MIT Voting Technology ed., Project Working Paper No. 79.

Nigeria, (1999). The Constitution of the Federal Republic of Nigeria.

Norris, Pippa (2012). "Why Electoral Malpractices Heighten Risks of Electoral Violence", Paper Presented at the Annual Meeting of the American Political Science Association, New Orleans, 30 August 2012.

Omotola, Shola J (2009). "Garrison' democracy in Nigeria: the 2007 general elections and the prospects of democratic consolidation”, Commonwealth and Comparative Politics vol.47, no.2, pp.195-221.

OSIWA (2012). "Making Elections Count: A Guide to Setting up a Civil Society Election Situation Room”.

OSIWA (2011). Election Management Bodies in West Africa: A Comparative Study of the Contribution of the Electoral Commissions to the Reinforcement of Democracy.

Pastor, Robert A. (1999). "The Role of Electoral Administration in Democratic Transitions: Implications for Policy and Research", Journal of Democratization, vol.6, no.4, pp.1-27.

Pottie, David (2001). "Electoral Management and Democratic Governance in Southern Africa", 28 POLITIKON 133.

Przeworski, Adam (1991). Democracy and the Market, University of Chicago ed.

Republican Party v. Malawi Electoral Commission and Others (2004). Constitutional Case No. 5, MWHC.

Sebudubudu, David., Osei-Hwedie, Bertha Z. (2005). Democratic Consolidation in SADC: Botswana's 2004 Elections.

South Africa (1996). The Electoral Commission Act (No 51).

Southall, Roger \& Fox, Roddy (1999). Lesotho's General Election of 1998: Rigged or Rigeur?, Journal of modern African Studies, vol.37, pp.669-688.

South Sudan (2012). National Elections Act.

Sisk, Timothy D (2008). "Elections in Fragile States: Between Voice and Violence", International Studies Association.

Sofie, Dreef and Wagner, Wolfgang (2013). "Designing Elections in Conflict-Prone Divided Societies: The Case of South Sudan", Peace Research Institute Frankfurt (PRIF)-Report No. 122.

Spigelman Hon. J (2000). "Seen to be done: The Principle of Open Justice”, Australian Law Journal, vol. 74, 290 (Pt. I), Id. 378 (Pt. II).

Sweeney, William, Chad Vickery and Katherine Ellena (2016). "Yes, The Presidential Election Could be Manipulated," The Washington Post, No.2.

Taylor, Charles (2018). Shared Security, Shared Elections Best practices for the prevention of electoral violence, A study by the American Friends Service Committee.

Tsikoane, Tumelo (2007). Democratic Consolidation in Southern Africa: Lesotho 19.

Tyler, Tom R. (2001). "The Psychology of Public Dissatisfaction with Government." In John R. Hibbing and Elizabeth Theiss-Morse, eds. What is it About Government that Americans Dislike? New York: Cambridge University Press.

Tyler Tom R (1988) "What is Procedural Justice: Criteria used by Citizens to Assess the Fairness of Legal Procedures", Law \& Society, vol.22, pp.103-128.

United States Agency for International Development (2010). Electoral Security Framework Technical Guidance Handbook for Democracy and Governance Officers.

United Nations Development Programme (2009). Elections and Conflict Prevention-A Guide to Analysis, Planning and Programming.

United Nations General Assembly Resolution 55/96, Promoting and Consolidating Democracy, UN Doc A/RES/55/96.

UNHCR GENERAL COMMENT NO. 32 U.N. DOC. CCPR/C/GC/32 (2007). "Article 14 encompasses the right of access to the courts in cases of determination of criminal charges and rights and obligations in a suit at law. Access to administration of justice must effectively be guaranteed in all such cases to ensure that no individual is deprived, in procedural terms, of his/her right to claim justice."

UNHRC General Comment 32, para 21; Council of Europe, Handbook on the Right to a Fair Trial, p 33.

Vorobyev D (2010). "Growth of Electoral Fraud in Non-Democracies: The Role of Uncertainty".

Wall, A., Rukambe, S., Ellis, J., Ayoub, A., Ayman, D., Carl (2006). Electoral Management Design: The International IDEA Handbook.

Zeev, M., and Russett B. (1993). Normative and structural causes of democratic peace, 1946- 1986. American Political Science Review, 87, 624-638;

Zimbabwe, (1979). The Constitution of Zimbabwe, Harare, Government Press. 